\title{
SOCIAL JUSTICE ACROSS THE ENGLISH CURRICULUM IN INDONESIAN SECONDARY SCHOOLS
}

\author{
SUGIONO \\ Universitas Nurul Jadid Paiton Probolinggo \\ ss.sugiono@gmail.com
}

\begin{abstract}
Social justice across curriculum is believed to entail changes in society, and thus the integration of social justice into curriculum comes to be crucial. Socially just curriculum deals with the principles of inclusive practices at schools, access to important knowledge and skills to all students, and the empowerment of students to act for socially just change. The purpose of this study was to investigate the extent to which the English curriculum in Indonesian secondary schools, year 10, is socially just. This study focused on documentary research, analysing the collected documents - the curriculum framework and school-based curriculum development - from the lens of socially just curriculum indicators. These indicators were constructed based on the state ideology, Pancasila (Five Principles) and prominent scholars' viewpoints of social justice covered in relevant literature. The results showed that most of all, those documents reflected the indicators for socially just curriculum. Nevertheless, to make a judgment as to whether the English curriculum is socially just is not a simple matter, since further research, which promotes talks with teachers and students, observation of classroom activities, analysis of methods of assessment, student textbooks, workbooks, and other resources, would be necessary to be done.
\end{abstract}

Keywords: social justice, English curriculum, Pancasila, society

\section{INTRODUCTION}

In the Indonesian context, social justice is based on the State's Five Ideological Precepts, known as Pancasila. It is recommended in its Explanatory Points that all Indonesians are to be just towards their fellow people and conform to an equal degree, equal rights, and equal obligations between individuals. Hence, these points appear to ideally place the life of the entire Indonesian citizens at the optimum point of the liberal conceptual view of social justice. According to Starr (1991, pp. 21-22), liberal view of social justice aims to limit the power of government, protect human rights and freedom and provide base opportunities for individuals to achieve their potential; the liberalism takes the concept of individualism through the belief that social justice could be achieved if individuals are intrinsically valued for both themselves and their culture and heritage.

Liberals define 'social justice' as 'fairness', which is highly likely to be achieved within particular social and political structures. Moreover, "liberals seek changes in public values, legislation and institutional structures so that everyone can achieve personal fulfilment and a voice in the mainstream; the liberal ideal is full participation in society for every individual" (Ibid, 1991, p. 22).

Accordingly, since the concept of social justice in the country is in line with that of liberal vision, it turns out that the individual rights are developed without neglecting the principles of social interests. Hence, the articulation of social justice in Indonesian education is to maintain the inclusivity at schools. "They [liberals] support the development of 'inclusive' practices which in the case of schools involves the promotion of an 'inclusive curriculum', and preferential treatment or 'affirmative action' for disadvantaged groups" (Ibid 1991, p. 22).

It is contended that curriculum will be the extension of multicultural education, integrated into competencies of all subjects as well as the process of learning that is relevant to enhancing students' understanding of pluralistic values, tolerance, and national unity (Improving People's Access to More Qualified Education 2004, p. 6). At this stage, presumably, constructions of curriculum of all subjects could be referred to the fundamental elements of social justice.

If English curriculum is constructed according to social justice principles, the content should enable students to participate fully in their society next to succeeding in their academic level. English subject, which is compulsory for all students at all levels, is to be the medium of providing coherent goals and learning experiences which prepare students to achieve their potential, to enhance their awareness of the importance of English in a competitive global 


\section{VOL. 01 NO. 01, JUNE 2020}

world, and to develop students' understanding of interrelatedness between language and culture (English Curriculum Framework 2006, p. 308).

Furthermore, according to Preston (2001, p. 215), schools could act as a bridge between the world of the home and the systems of society. It is then of great importance for educational practitioners and teachers, particularly English teachers, to think that social justice across the curriculum can entail social change. Students can achieve much both academically and socially by implementing a socially just curriculum. Taking the analogy of Noddings' work Teaching Themes of Care (2003 pp. 59-60), "the inclusion can expand students' cultural literacy, connect the students to the subject, relate teacher to students person-to-person, in the sense that when the teacher is explaining, he/she might become a real person to the students, and so enable them to construct new knowledge". Thus, the integration of social justice into curriculum will imply a continuous search for competence, and is not anti-intellectual. Rather, it can demonstrate respect for the full range of student's talents.

The study focuses on answering the following questions:

1. What is the vision of society that underpins the English curriculum documents?

2. What indicators of inclusiveness and fairness are represented in the English curriculum documents?

3. How is social responsibility embedded in the English curriculum documents?

This study focuses on documentary research, viewing the collected documents from the social justice standpoint covered in relevant literature. Print (1993, pp. 6-7) stipulates that learning more about curriculum will develop a clearer perspective of what is perceived as its nature, and in that process reflect upon one particular characterization which views curriculum as cultural reproduction, in the sense that curriculum should reflect the culture of a particular society. "If schools are to function as a mirror of society, they must keep pace with social and cultural change when curriculum is planned" (Brady, 1992, p. 40). Apart from that, due to the fact that the school-based curriculum development has just been nationally implemented in Indonesia, this study result could be an invaluable source of inspiration to the scholars to conduct further research.

Three out of twenty seven secondary schools in Probolinggo Regency are selected and looked upon the issues of justice in terms of their distance; closer, middle, and farther from the local educational administration respectively. Besides, the status of the schools is also taken into account; state school, private school, and private school under Pesantren (Islamic Boarding School). State school is closer to the local government, seems to be given more priority and attention, and is inclined to become a centre of any particular educational activities. Such documents as explanatory points of the State Ideology, Pancasila (Five Principles), and Peraturan Menteri Pendidikan Nasional Republik Indonesia (Ministry of National Education Regulations of Republic of Indonesia) are then collected and so are English Curriculum Framework and School-based Curriculum Development of the three schools.

The documents will be analysed using Qualitative Content Analysis Method, which is part of Discourse Analysis Methodology of Qualitative Research. Despite the argument that documentary research method has had little attention compared to other methods on account of the dominance of positivism and empiricism, employing a range of documentary sources such as state government files will enable the researcher to reflect on contemporary issues, and see how new questions arising from contemporary concerns such as gender issues, racism, and nationalism could be uncovered (Qualitative Research Methods: Documentary Research 2007, p.1). Concerning the process of applying the documentary research in this project, the first thing that the researcher does is classifying documents in terms of whether those documents are primary, secondary, or tertiary; public or private. Second, conceptualizing documents; at this stage, the theoretical perspective of critical inquiry will be applied. It is contended that critical inquiry sees documents "as media through which social mechanisms, structures and powers are expressed, and so should be approached in terms of cultural context in which they were written" (Qualitative Research Methods: Documentary Research 2007, p.2). Approaching 
documents in this way can provide the researcher with a lot of information on the societies in which writers write and readers read (Ibid 2007, p.2). Thus, a document, in this respect, might be assumed reflecting the marginalization of particular groups of people. Third, assessing documents; in this step, the researcher assesses the quality of the evidence from the documentary sources based on the authenticity and credibility of the documents (Hitchcock \& Hughes 1989, p. 126; Bryman 2004, p. 381). Fourth, analyzing documents; in this stance, the researcher focuses upon the relationships within the text and its relationship with other texts, and considers how the documents close off potential contrary interpretations to the reader. Besides, he also looks on the way in which a text attempts to stamp its political and cultural authority upon the social world it describes, based on the assumption that the social world might be characterized by the exclusion of valuable information, for instance, on women and other minority groups, and the characterization of events and people in particular ways in accordance with certain powerful interests.

\section{REVIEW of LITERATURE}

'Social justice' and 'curriculum' are contested terms. Experts define those terms in many different ways according to their intellectual perspectives. 'Socially Just Curriculum' acknowledges that social justice could be a philosophical foundation of curriculum constructions. The philosophical word 'social justice' in this context will be unhelpful unless it is made clear. Therefore, this section will explore understandings of 'social justice' and 'curriculum' respectively, prior to explaining 'socially just curriculum'. Besides, 'indicators for socially just curriculum in Indonesia' will also be covered.

\section{Social Justice}

Pozzuto (2006, p. 84), using the work of Behr (2003), has noted that Luigi Taparelli D'Azeglio, S.J. was the one who first used the term 'social justice'. It is contended that Taparelli's 1840-1843 work entitled Theoretical Treatise on Natural Right Based on Fact elaborates a natural-law approach to politics and social justice. In Taparelli's mind, social justice seems to reflect the Eternal Law determined by God.

"Taparelli's natural approach to social justice is an explication, within the limits of human capability, of God's principles. Taparelli built a model of the ideal society that consisted integrated, hierarchical structures, larger and smaller societies, each having their own ends but each also integrated into the common good as found in the natural law. Taparelli's ultimate source, as stated above, is God, the author of all that exists" (Pozzuto, 2006, p. 84).

Despite the emergence of the enlightenment period, which gives an important position to reason and the application of logical, rational and analytic thought through human intelligence rather than God, some experts insinuate that Taparelli's view is a fundamental basis of establishing a theory of social justice. His approach is considered to coordinate between human thinking and the Eternal Law of God.

"...though those rooted in the enlightenment have not entirely broken from the natural law perspective" (Pozzuto 2006, p. 85).

"Justice everywhere derives from religious beliefs, and our western ideas of justice emerge from Christianity. But western ideas of justice have equipped themselves with a philosophical foundation which has persuaded Europeans that our practices instantiate justice tout court" (Minogue 1998, p. 254). 


\section{VOL. 01 NO. 01, JUNE 2020}

Similarly, the notion of social justice in Indonesia is based on Pancasila (Sanskrit word, which means 'five principles' or 'five precepts' or 'five pillars'). Pancasila itself derives from religious beliefs and past injustice experiences of Dutch, England, and Japan colonialism. It was first constructed collaboratively on $1^{\text {st }}$ of June 1945, 76 days prior to the Independence Proclamation, by scholars who had strong commitment to the ideals of religion. The five pillars, which eventually became the state important foundation, were Islam-inspired agenda (Hosen 2005, p. 424). Those principles have been virtually accepted by all Muslim, secular and non-Muslim leaders as they contain a lot of diversity and plurality, not only in terms of ethnicity and culture, but also in terms of religion (Azra 2006, p. 2).

"The Pancasila-based state, which begins with the principle of 'One Godhead', not only allows, but also encourages, [any] religion to inspire Indonesian public life in humanitarianism, national unity, representative democracy and social justice" (Hosen 2005, p. 424).

However, since social justice is conceptualized contextually rather than definitively and has different meanings and significance in diverse circumstances, it is extremely hard to find consensus among a group of prominent scholars as to the definitive understanding of social justice. Sturman (1997, p. 1) contends that "the concept of 'social justice' fits into this category: it is not clearly defined (in fact, the term is often used as a synonym for "equal opportunities' or 'equity') and it is value-laden".

"It is now relatively uncontroversial, even in philosophical circles, to suggest that the idea of social justice does not have a single essential meaning - it represents discourses that are historically constituted and it is a site of conflicting and divergent political endeavours" (Rizvi \& Lingard 1993, p. 5 as cited in Sturman).

One of the best examples of an essentially contested concept of social justice is the concept of distributive justice. The major advocate of the distributive theory of social justice was John Rawl's book A Theory of Justice published in 1971. This book is stated to turn much of modern political theory in Britain and the United States into a discipline focused on issues of distribution. Sturman (1997, p. 3) has noted Rawl's argument that the primary area over which justice presides is the distribution of primary goods, such as wealth, position, opportunity, and liberty. Miller (1999 as cited in Harrison), a leading contemporary philosopher of social justice, puts it, "when we talk and argue about social justice, what exactly are we talking and arguing about? Very crudely, I think, we are discussing how the good and bad things in life should be distributed among the members of a human society" (p. 12).

Rawls also conceptualized two principles when referring to the problem of a just basic structure: First, each person should have an equal right to an extensive system of equal basic liberties; and second, social and economic inequalities should be arranged so that they are to the greatest benefit of the least advantaged (the Difference Principle) and attached to offices and positions open to all under conditions of fair equality of opportunity.

Thus, social justice philosophies may be classified into two groups; individualistic and communitarian. The former refers to the position and life experience of individuals and concerns about liberty, entitlements, and reduction of inequality of individuals, based on the assumption that individual liberty is an essential prerequisite for the achievement of social justice. The latter sees that the notion of shared community beliefs about living and justice is essential.

The promotional concept of social thinking among individuals, too, belongs to liberals and Pancasila, which clearly stands at the liberal view of social justice. Young (1990 as cited in Sturman 1997, p. 23) argues that the distributive approach to social justice fits within the liberal notion of social justice. Starr (1991, pp. 22) stipulates that liberals stress the need for 


\section{VOL. 01 NO. 01, JUNE 2020}

individuals to develop a strong sense of self-esteem and individual worth, which is believed to develop an ethos of tolerance, acceptance, and valuing others.

"Given time, new attitudes, practices and values will pervade society catalyzing major alterations in society's deepest psychological consciousness, leading to greater social justice and cohesion" (Ibid 1991, p. 22).

Whereas, self-esteem, the ideas of acceptance and valuing others constitute fundamental substances of Pancasila. These substances are covered in the second and fifth precepts: 'Just and civilized humanity' and 'Social justice for the whole of the people of Indonesia'.

In other words, Pancasila counts the evidence of both individualistic and communitarian. The former specifies that Pancasila recommends individuals for unity in diversity, good care of motherland, participation in democracy, and conformity with equal degree and rights, while the latter for their roles in society, which include tolerance for people of different religions, respect for other people's rights, cooperation with other nations, love of human being, justice towards fellow people, and help for one another (Pancasila (Five Principles) 2008, pp. 1-2).

\section{Curriculum}

Posner (1992, p. 1) argues that one of the basic questions that is important to answer when beginning curriculum study is 'what is curriculum?' It is inevitable in that people might have different claims when they use the term 'curriculum'. The word can be used in many different contexts by school principals and teachers, by curriculum writers, or even by politicians. However, Smith and Lovat (1993, p. 1) argue that arriving at a particular definition of 'curriculum' is not the most important part.

"What is far more important is to recognize that people do use the word to mean different things and we need to make sure that we understand the meaning that is being given to the word; each usage and meaning of the word is embedded within a particular ideology or set of beliefs about education and the world; different usages and meanings of the word suggest a number of issues and concerns that are central to the nature of the curriculum work itself" (p. 1).

It is stated that the word 'curriculum' is originated in the civilization of the ancient Greeks, and derives from the Latin word 'curro' (I run) or 'currere', which may be interpreted not as a 'racecourse' but rather as 'the running of the race' (Print 1993, p. 6; Posner 1992, p. 5). "The 'curriculum', for the ancient Greeks, was a running track around which athletes would run and compete" (Smith and Lovat 1993, p. 2). Curriculum as a running track deals with curriculum as the interpretation of lived experience, which emphasizes the individual's capacity to participate upon his/her experience of life and promotes an experiential perspective to learning. Hence, sharing experiences and re-conceptualizations is considered a social process that will make individuals [students] achieve a greater understanding of themselves as well as others and the world (Print 1993, p. 6).

Besides, the running track for curriculum is regarded as an analogy which provides the opportunity to explore such issues as gender, social class, race and physical and mental disability. Smith and Lovat (1993) point out:

"One can think of many running tracks that are able to symbolize different education systems. For example, a running track can be in straight lines or circular. The runners might be males or females or of both genders. They might be handicapped or have staggered starts. If we think of the characteristics that different running tracks might have, we should also be able to identify different types of curriculum, or factors which are important in providing an effective curriculum for learners" (p. 2). 
Moreover, Smith and Lovat (1993, pp. 4-5) list a number of definitions of curriculum that have been used by different people at different times. The focus is not on the definition itself but rather on the perspectives behind the definitive statement, which is believed to reflect the historical, social, economic, and political context in which it was derived. By means of particular perspectives of viewing curriculum, analysis of a series of definitions of curriculum can provide a sound understanding of what curriculum is. To gain any complete, useful and effective definition of curriculum, Grundy (1994, pp. 29-31) suggests that the following perspectives be included; the pedagogical perspective and the syllabus perspective of viewing curriculum.

The pedagogical view of curriculum refers to thinking about curriculum as an action or process. The view deals with the work of teachers in planning and organizing the learning experiences for the class. In this stance, there are four components of schooling identified; those are teachers, students, subject-matter and milieu. The identification is based on assumption that it would be difficult to understand the nature of the curriculum unless a consequence of the dynamic interaction of all those four components was recognized. The definitions of curriculum below might be within the pedagogical perspective:

1. "Curriculum is the planned learning experiences of students for which the school is responsible" (Smith and Lovat 1993, p. 4).

2. "Curriculum is all planned learning outcomes or desired consequences of the instructor for which the school is responsible" (Ibid).

Meanwhile, the syllabus view of curriculum is concerned with considering curriculum as an object or product. The basic component of the curriculum, according to this view, is designed by expert curriculum designers and developers, and given to those for whom it is intended. Viewing curriculum as an object or product commonly defines curriculum as subjects or disciplines or syllabuses and documents. It takes no account of what takes place in the classroom, when the subjects or disciplines are being taught, what strategies and activities are being applied, what experiences students are getting, or what learning processes are occurring. The definitions below may reflect this perspective:

1. "Curriculum is one that should consist entirely of knowledge from the disciplines" (Ibid). 2. "Curriculum is the syllabus, a course of study or subjects" (Ibid).

Grundy (1994, p. 32), however, states that such official documentation as syllabus documents are merely texts that still need interpretation; they do not represent the curriculum. Even, in some cases, she identifies a contradiction between what students learn in school and the officially documented curriculum. At this stage, it turns out that she is signalling a hegemonic view, which makes the pedagogical perspective looks more crucial.

Both views are crucial in the sense that no particular view is superior to the other. Syllabus or curriculum documentation can be made as a hypothesis or assumption to be tested in the pedagogical process. Therefore, a useful definition of curriculum which stands in both perspectives of object or product, action or process, and intention or reality is constructed. Such a notion of curriculum is reflected in Smith and Lovat (1993):

"On the one hand, curriculum as intention comprises a progressively modifiable plan of areas of learning and growth for an individual or a group of learners focused upon an educational centre, incorporating a set of objectives, a set of learning experiences and suggestions for their organization and techniques for evaluation of learning outcomes. On the other hand, curriculum as reality is what actually happens to the person or persons, arising from a complex network of interactions between people responding to a diverse array of influences, explicit and implicit, human and physical" (p.4).

In this study, the researcher confines the definition to the syllabus perspective of viewing curriculum as planned documents rather than implemented ones. Curriculum, from an 
Indonesian perspective, constitutes a written document which contains a number of goals and objectives and comprises guidelines on learning programs in terms of what to teach (a course of subjects), how to teach (methodology), and how to assess (evaluation); all are written in documentation called curriculum. Schoolteachers in the country come to think that what is implemented in the classroom is and/or must be in line with what has been previously planned or written in the document. Otherwise, they will be regarded as having deviated from the documented script.

\section{Socially Just Curriculum}

Connell (1993, p. 11) has opposed the idea that questions about education and questions about social justice are separated from each other. The reason for his opposition is that not only is the education system a major public asset which is likely to become more important in the future, but also it forms a particular kind of society that will come into being. This means that whether or not the future society will be a just society partly depends upon the use of current education system. Education for social justice can be both a goal and a process, building something not necessarily achievable in today's lifetime (McDaniel, et al 2001, p. 56). It should include a vision of society and students' social responsibility towards others and society as a whole. Through the process of schooling, students will be made aware of the reality that they constitute members of society.

To bring that all about, the integration of social justice into curriculum is critical. In other words, socially just curriculum, as well as teachers' work, should be given central roles in that process. Barlow (1989, p. 17) contends that socially just curriculum should do two things: First, give access to important knowledge and skills to all students, and second, empower students to act for socially just change. Penney and Walker (2007), partly using the work of Quickle (1999, p. 14), elaborate:

"Our concern is in the capacity of the curriculum reform to prompt and support the development of an inherently more inclusive and socially democratic system of schooling and future society; that is a system that seeks to develop skills, knowledge and understandings that will empower more learners to play an active part in the betterment of society from a social justice perspective; a system which is suited to the capabilities of all members of society rather than just those of an academic elite and that recognizes all members' capabilities as valuable in relation to the development of society" (p. 23).

Moreover, according to the liberal tradition of social justice, socially just curriculum has been based on the principles of inclusive practices, fair competition, and equitable opportunity (Starr 1991, pp. 21-22; Sturman 1997, p. 22). Social justice across the curriculum might be considered to exist when the curriculum is inclusive to all individual students, and individual students receive what they deserve on the grounds of ability.

“...there is an emphasis on the potential capacity of individual [students'] rights to deliver social justice. Hence, the primary concerns are ones of resourcing and access" (Young 1990 as cited in Sturman 1997, p. 23).

\section{Indicators for Socially Just Curriculum in Indonesia}

In the Indonesian context, socially just curriculum must be designed or constructed with reference to the State Ideology, Pancasila. Previously, it has been shown that Pancasila incorporates a vision of Indonesian society which stands at the conceptual points of both individualistic and communitarian. Hence, drawing from Pancasila, and from the ideas of such prominent scholars as Barlow (1989), Starr (1991), and Sturman (1997), indicators for identifying the extent to which the curriculum is socially just are to be established. The table below incorporates the socially just curriculum indicators. 
VOL. 01 NO. 01, JUNE 2020

Table 1: Socially Just Curriculum Indicators

\section{INDICATORS}

VISION OF SOCIETY

- Unity in diversity (Pancasila, 2008)

- Good care of motherland (Pancasila, 2008)

- Participation in society/democracy (Starr, 1991; Pancasila, 2008)

- Empowerment to act for socially just change (Barlow, 1989)

INCLUSIVENESS AND FAIRNESS

- Inclusive language (Starr, 1991)

- Fair competition (Starr, 1991; Sturman, 1997)

- Equality of opportunity (Sturman, 1997)

- Conformity with equal degree and rights (Pancasila, 2008)

- Provision of access to important knowledge and skills to all students (Barlow, 1989)

SOCIAL RESPONSIBILITY

- Tolerance/Respect for people of different religions (Starr, 1991; Pancasila, 2008)

- Valuing of all people/Respect for other people's rights (Starr, 1991; Pancasila, 2008)

- Cooperation with other nations (Pancasila, 2008)

- Love of human being (Pancasila, 2008)

- Justice towards fellow people (Pancasila, 2008)

- Help for one another (Pancasila, 2008)

\section{RESULTS OF THE STUDY}

This part will analyse the English curriculum framework, using the indicators for socially just curriculum as outlined above. Prior to the analysis, a brief description of the document will be provided in relation to the type and classification of the document, the creator of the document, and the rationale and purposes of making the document. With reference to Hitchcock and Hughes (1989, p. 126) and Bryman (2004, p. 381), the description is aimed at assessing the authenticity and/or credibility of the document.

\section{The English Curriculum Framework}

The document Standar Kompetensi dan Kompetensi Dasar Sekolah Menengah Atas Mata Pelajaran Bahasa Inggris (Standard Competence (Goals) and Basic Competence (Learner Objectives) of English Subject for Secondary Schools) constitutes the framework for the English curriculum as well as a primary source of this project. It is an official public document issued by the Indonesian central government through the national ministry of education. It was constructed by a team of various educational experts via collaborative work between Pusat Kurikulum (Curriculum Centre), Badan Penelitian dan Pengembangan (Research and Development Board), and Badan Standar Nasional Pendidikan (National Education Standard Board) (Ministry of National Education Regulations of Republic of Indonesia 2006, p. 5). The experts are drawn from prominent universities, schools, and other related institutions; they could be lecturers, teachers, and educational researchers that are, nationally, believed to have expertise in their own educational disciplines (Indonesian National Education Standard Board, 2006). 
The construction of the curriculum framework is based on the implementation of the state ideology, Pancasila. It is stated in the National Education Standard Board (2006, pp. 7-9) that curriculum is constructed to enhance students' faith, piety, and good character by ensuring the maintenance of tolerance and harmony with people of different beliefs. Apart from that, curriculum is directed to improve international relations, unity in diversity, understanding and appreciation of local, national and international cultures, and to attain social justice, particularly gender equity, in the national education.

The document consists of eight pages, for year 10, and is comprised of the following four major sections (translated from the original document):

Section A : Background of Document Construction; it deals with the rationale for constructing the document.

Section B : Purpose of Document Making; it relates to the development of students' communicative competence, students' awareness of the importance of English language, students' perception of the interrelatedness between language and culture.

Section C : Scope of English Subject for Secondary Schools; it concerns the ambit of English language learning, which covers discursive competence and such other competencies as linguistic competence, socio-cultural competence, and strategic competence.

Section D : Standard Competence (Goals) and Basic Competence (Learner Objectives) of English Subject for Secondary Schools Year 10 Semester 1 and Semester 2; this covers four major skills - listening, speaking, reading, and writing skills. The table below presents the sample of listening and speaking skills of the curriculum framework.

Table 1: Sample of English Curriculum Framework Year 10 Semester 1 for Listening and Speaking Skills (translated as the original document)

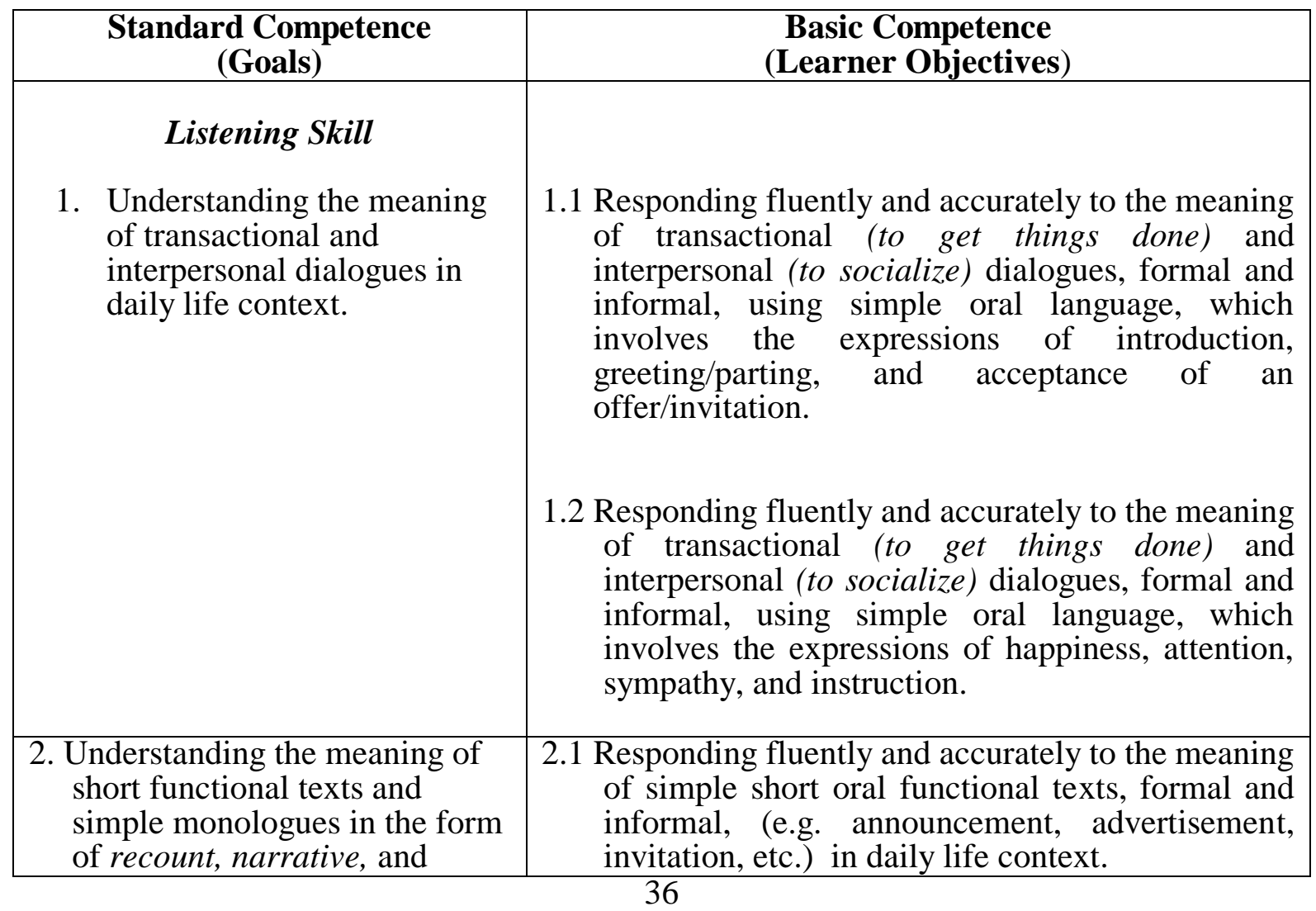




\section{VOL. 01 NO. 01, JUNE 2020}

\begin{tabular}{|c|c|}
\hline procedure in daily life context. & $\begin{array}{l}\text { 2.2 Responding fluently and accurately to simple } \\
\text { monologues using oral language in daily life } \\
\text { context: recount, narrative, and procedure. }\end{array}$ \\
\hline $\begin{array}{l}\text { Speaking Skill } \\
\text { 3. Expressing the meaning of } \\
\text { transactional and interpersonal } \\
\text { dialogues in daily life context. }\end{array}$ & $\begin{array}{l}\text { 3.1 Expressing fluently and accurately to the meaning } \\
\text { of transactional (to get things done) and } \\
\text { interpersonal (to socialize) dialogues, formal and } \\
\text { informal, using simple oral language, which } \\
\text { involves the expressions of introduction, } \\
\text { greeting/parting, and acceptance of an } \\
\text { offer/invitation. } \\
\text { 3.2 Responding fluently and accurately to the meaning } \\
\text { of transactional (to get things done) and } \\
\text { interpersonal (to socialize) dialogues, formal and } \\
\text { informal, using simple oral language, which } \\
\text { involves the expressions of happiness, attention, } \\
\text { sympathy, and instruction. }\end{array}$ \\
\hline $\begin{array}{l}\text { 4. Expressing the meaning of short } \\
\text { functional texts and simple } \\
\text { monologues in the form of } \\
\text { recount, narrative, and } \\
\text { procedure in daily life context. }\end{array}$ & $\begin{array}{l}\text { 4.1 Expressing fluently and accurately to the meaning } \\
\text { of simple short oral functional texts, formal and } \\
\text { informal, (e.g. announcement, advertisement, } \\
\text { invitation, etc.) in daily life context. } \\
\text { 4.2 Expressing fluently and accurately to simple } \\
\text { monologues using oral language in daily life } \\
\text { context: recount, narrative, and procedure. }\end{array}$ \\
\hline
\end{tabular}

The rationale for the document relates to how language in general and English language in particular is viewed. It states that language plays an important role in the development of students' intellectual, social, and emotional competence, and can be a means of engaging in all fields of study. Language study helps students respect their own and other cultures, express ideas, participate in society, and develop their analytic and imaginative competence. With this philosophical view of language, the reason for constructing the English curriculum document is connected with the fact that English is a means of communicating information, ideas, feelings, and developing knowledge, technology, and culture. Thus, the English language learning is directed to 'communicative competence', and also 'discursive competence'. These competencies are the foundations for understanding and/or producing oral and/or written texts and they reflect the four macro skills (listening, speaking, reading, and writing). It is these skills which will later be used to create or respond to discourse in the society (Ibid, 2006).

Nationally, the English language learning for secondary schools adopts the three following purposes:

1. Developing students' communicative oral and written competence to attain informational literacy level. 


\section{VOL. 01 NO. 01, JUNE 2020}

2. Encouraging students' awareness of the essence of English language as a tool of improving nation's competitive potency in the global society.

3. Developing students' understanding of the relationship between language and culture.

Analysis

Recently there has been much debate about the desirability and impact of the spread of English. Taki (2008, p. 128), using the work of Phillipson (1992) and Skuttnab-Kangas (1999), notes that the spread of English has its strong critics who view global English as a means of linguistic imperialism. "Once Britannica ruled the waves, now it is English which rules them; the British empire has given way to the empire of English" (Phillipson 1992, p. 1). From this point of view, metaphorically speaking, constructing English curriculum could be considered one form of promoting imperialistic practices. The term 'imperialism' itself, connotatively, is not neutral and tends to be negative, for it is frequently connected with social injustices and opposed to other people's freedom and rights. However, Warschauer (2000 as cited in Taki) maintains that "English is neither good nor bad. To declare that English is unequivocally harmful or beneficial is to deny the human agency which shapes how English is used in different circumstances". Moreover, Widdowson (1997 as cited in Taki) stipulates that "English has spread as an international language through the development of a particular expert community, which guarantees specialist communication within global expert communities". At this stage, Taki (2008, p. 127) specifies that competence in English is viewed as a tool for inclusion into certain realms, and consequently, English language teaching is perceived as an asset.

In the Indonesian context, there has been more English language teaching over the past decade. English is one of the required subjects in the national mainstream education system, which is taught from primary schools to universities. In secondary schools, year 10, English is taught for $4 @ 45$ minutes lessons a week. Since English language teaching in the country is conducted against different cultural backgrounds, questions of social value and ideology are inevitable. In general, critical discourse analysis deals with the situated use of language in a certain socio-cultural contexts, and thus it is assumed that the use of language constitutes the crystallization of a certain ideology (Taki 2008, p. 128). Hence, it might be of great interest to know whether the English curriculum design consistently follows any particular social ideology, or whether any particular social ideology has become concern from the curriculum designers.

Table 1 shows that the English curriculum framework contains broad rather than specific guidelines. According to Marsh (1992, p. 75), using curriculum frameworks can be advantageous. He adds that "if frameworks become too detailed, they can become very directive for teachers". Detailed frameworks may reduce teachers' freedom in the curriculum development phase at the school level.

Meanwhile, from the perspective of the researcher, there seems to be some tension between the broad curriculum content and the process of identifying social issues in it. With broad guidelines, it is difficult to ascertain the extent to which the curriculum design explicitly represents the socially just curriculum indicators. Nevertheless, in both 'standard competence (goals)' and 'basic competence (learner objectives)' of the curriculum, semester 1 and semester 2, there are several phrases which essentially contend that the goals of English learning across the macro skills (listening, speaking, reading, and writing) are to understand, express, and respond to the meaning of transactional and interpersonal conversations/dialogues within daily life contexts, and to understand, express, and respond to the meaning of short functional texts and simple monologues in the form of recount, narrative, procedure, descriptive, and news item. The response to the transactional and interpersonal dialogues implies formal and informal socialization within daily life contexts using the functional expressions, which include expressions of introduction, accepting and declining an offer/invitation, praise, sympathy, thanks, congratulation, and surprise. These are matters of social justice. 
Furthermore, reading those phrases, the curriculum framework refers to the philosophical perspective of education for relevance. "Education for relevance might mean learning marketable skills, studying culture, or becoming social [justice] activists" (Posner 1992, p.45). Besides, it seems that the curriculum designers concern for the socio-political conflicts which preceded the emergence of Reform Movement demanding de-centralization in all aspects, including education. "For each historical period, there is an underlying sociopolitical philosophy impacting on curriculum (Smith and Lovat 1993, p. 5). Providing students with lessons about socializing with other people in real life context is in line with the vision of Indonesian society which implies 'an act of empowering students for socially just change' and the essence of 'participation in society' for the promotion of peace reflected in 'unity in diversity'. The latter is also contained in the third purpose of the framework: "Developing students' understanding of the relationship between language and culture" (p. 2). Aside from it, the indicators 'participation in society' as well as 'respect for other people's rights' are obviously represented in the philosophical view of language stated in the rationale for constructing the document: "Language study helps students respect their own and other cultures, express ideas, participate in society..." (p. 1). The following table enumerates the presence of social justice indicators in the English curriculum framework.

Table 2: Socially Just Curriculum Indicators in the English Curriculum Framework

\begin{tabular}{|c|c|c|}
\hline Indicators & $\begin{array}{c}\text { Yes/N } \\
0\end{array}$ & $\begin{array}{c}\text { No. of } \\
\text { Statement } \\
\text { s } \\
\end{array}$ \\
\hline $\begin{array}{l}\text { VISION OF SOCIETY } \\
\text { Unity in diversity } \\
\text { Good care of motherland } \\
\text { Participation in society/democracy } \\
\text { Empowerment to act for socially just change }\end{array}$ & $\begin{array}{l}\text { Yes } \\
\text { Yes } \\
\text { Yes } \\
\text { Yes }\end{array}$ & $\begin{array}{l}2 \\
1 \\
2 \\
1\end{array}$ \\
\hline $\begin{array}{l}\text { INCLUSIVENESS AND FAIRNESS } \\
\text { Inclusive language } \\
\text { Fair competition } \\
\text { Equality of opportunity } \\
\text { Conformity with equal degree and rights } \\
\text { Provision of access to important knowledge and skills to all } \\
\text { students }\end{array}$ & $\begin{array}{l}\text { Yes } \\
\text { Yes } \\
\text { Yes } \\
\text { Yes } \\
\text { Yes }\end{array}$ & $\begin{array}{l}\text { All } \\
1 \\
1 \\
1 \\
1\end{array}$ \\
\hline $\begin{array}{l}\text { SOCIAL RESPONSIBILITY } \\
\text { Tolerance/Respect for people of different religions } \\
\text { Valuing of all people/Respect for other people's rights } \\
\text { Cooperation with other nations } \\
\text { Love of human being } \\
\text { Help for one another }\end{array}$ & $\begin{array}{l}\text { No } \\
\text { Yes } \\
\text { Yes } \\
\text { Yes } \\
\text { Yes } \\
\text { Yes }\end{array}$ & $\begin{array}{l}- \\
8 \\
1 \\
6 \\
1 \\
1\end{array}$ \\
\hline
\end{tabular}

The functional expressions of the frameworks are, too, closely connected with most of the socially just curriculum indicators. For example, learning expressions of praise, thanks, congratulations, surprise, acceptance of an offer or invitation and sympathy might be related to 


\section{VOL. 01 NO. 01, JUNE 2020}

'valuing of all people' and 'love of human being'. In the meantime, studying expressions of introduction might be extended to 'equitable opportunity', 'conformity with equal degrees and rights', or 'justice towards fellow people'. The reason is that in Indonesian culture, introduction is commonly carried out in a formal situation, and this formality helps to maintain balanced communication and 'respect for one another'. As soon as these indicators are obtained, 'help for one another' will automatically be present. In addition, the indicators 'fair competition', 'cooperation with other nations', and 'good care of motherland' are covered in the second purpose of the document construction, that is to say, "encouraging students' awareness of the essential function of English language as a means of enhancing nation's competitive potency in the global society" (p. 2). In order for the country to win the competition in the global world, fairness and stepping up bilateral or multilateral agreements with other countries should be taken into account. Besides, with the phrase 'students' awareness...improving nation's competitive potency', students' patriotism and nationalism could be enhanced; patriotism and nationalism are associated with a person's great love for his/her nation.

In terms of the language, the words, phrases, and sentences used in the document are neutral and inclusive in the sense that no words, phrases, and sentences comprise bias in gender, race, ethnicity, and religion, implying that 'all students' deserve 'access to important knowledge and skills'. However, it is noted that there is one component of the indicators which is not explicitly included in the document, that is to say, 'tolerance/respect for people with different religions'. There has been a strong perception in Indonesia that the topic 'tolerance/respect for people with different religions' has become the core responsibility of Civics, not English. Nonetheless, the National Education Standard Board (2006, p. 8) has recommended that all school subjects should include the aspect of 'religion' in curriculum constructions.

Thus, it could be stated that the English curriculum framework covers almost the entire socially just curriculum indicators outlined in the previous part. Table 2 has shown that the framework gives more emphasis to the enhancement of students' 'social responsibility' rather than 'vision of society' and 'inclusiveness and fairness', especially in terms of both 'valuing of all people/respect for other people's rights' and 'love of human being'. In the next part, the researcher will describe and analyse the English school-based curriculum development, which is the extension of the centralized curriculum framework, to know the extent to which this document represents the indicators of socially just curriculum.

\section{English School-Based Curriculum Developmenet (SBCD)}

This section will analyze Kurikulum Tingkat Satuan Pendidikan (KTSP) Sekolah Menengah Atas Mata Pelajaran Bahasa Inggris (English School-based Curriculum Development for Secondary Schools) with reference to the indicators for socially just curriculum. As for the previous section, the research will briefly describe the document in terms of the type and classification of the document, the writer(s) of the document, the rationale and purposes of constructing the document, which is aimed at measuring the authenticity and/or credibility of the document (Hitchcock \& Hughes 1989, p. 126; Bryman 2004, p. 381).

As for the English curriculum framework, the document Kurikulum Tingkat Satuan Pendidikan (KTSP) Sekolah Menengah Atas Mata Pelajaran Bahasa Inggris (English Schoolbased Curriculum Development for Secondary Schools) is also the primary source of this study. This document, which is both official and public, was constructed by a group of English teachers of both private and state secondary schools at the regency level under Musyawarah Guru Mata Pelajaran (MGMP) (English Teachers' Network Association). This association conducts its monthly meeting with the main agenda for sharing ideas of the curriculum implementation at the school level and strategies for students' high achievement in the national exams. SBCD is the extension of the curriculum framework to which the standard 
competence (goals) and the basic competence (learner objectives) refer. The purpose of implementing SBCD, as stated in the editorial of the National Curriculum Centre, is for schools to develop the uniqueness of their human resource potency and local environments.

The English teachers' network association $(M G M P)$ has developed learning materials, learning activities, learning experiences, assessment, time allotment, and resources for each of the standard competence (goals) and the basic competence (learner objectives) that are contained in the curriculum framework.

The rationale that underpins SBCD is the notion that when a curriculum has been designed, it should then be developed, "probably to become a written document and finally to be implemented and evaluated" (Print 1987, p. 15). School teachers are responsible for the development as they are regarded as front-line problem-solvers of schooling and educators having more knowledge of students' needs. Apart from that, SBCD may "oppose the bureaucratic, hierarchical, centralized approach to curriculum development" (Ibid).

Despite several potential problems with SBCD, for instance, lack of time for teachers to undertake SBCD, lack of teachers experienced or trained in the process of SBCD, and requirement for significantly changing roles of school teachers, it does not mean that SBCD should not be implemented. The solution may lie with the provision of socialization and training programs by the Ministry of National Education and the enhancement of coordination among schools through the improvement of existing teachers' networks. Besides, according to the logic of SBCD, "local teachers are those who are in best position to appreciate the needs of a specific group of learners, which, in turn, has a powerful impact upon learners; those who implement the curriculum are those who develop it, which gives a greater sense of identification with the learning tasks; and greater accountability of the curriculum and teacher performance will be noticed" (Print 1987, p. 14).

The English School-based Curriculum Development for Year 10 is comprised of 13 pages and consists of four major sections (translated as the original document):

Section A : Background of Curriculum Construction; it refers to the rationale for constructing the curriculum framework.

Section B : Purpose of Curriculum Construction; it relates to the general purpose of national education, that is to say, to raise the standard of intelligence, knowledge, personality, and skills.

Section C : Structure and Content of the English School-based Curriculum Development for Secondary Schools Year 10 Semester 1 and Semester 2; this comprises standard competence (goals) and basic competence (learner objectives) which refer to those of the framework, learning materials, learning activities, learning experiences, assessment, time allotment, and resources.

Section D : Education Calendar; it describes effective school days and holidays in reference to the national education at the province level.

The table below specifies the sample of listening and speaking skills of the school-based curriculum development 
VOL. 02 NO. 01, JUNE 2020

Tabel 1: Sample of the English School-based Curriculum Development Year 10 Semester 1 for Listening and Speaking Skills (translated as the original document)

\begin{tabular}{|c|c|c|c|c|c|c|c|}
\hline $\begin{array}{c}\text { Standard } \\
\text { Competenc } \\
\text { e } \\
\text { (Goals) }\end{array}$ & $\begin{array}{c}\text { Basic } \\
\text { Competenc } \\
\text { e } \\
\text { (Objetives) } \\
\end{array}$ & $\begin{array}{l}\text { Learning } \\
\text { Materials }\end{array}$ & $\begin{array}{l}\text { Learning } \\
\text { Activities }\end{array}$ & $\begin{array}{c}\text { Learning } \\
\text { Experienc } \\
\text { es }\end{array}$ & $\begin{array}{l}\text { Assess } \\
\text {-ment }\end{array}$ & $\underset{\text { e }}{\text { Tim }}$ & Resources \\
\hline $\begin{array}{l}\text { Listening } \\
\text { 1.Understand } \\
\text { - } \\
\text { ing the } \\
\text { meaning of } \\
\text { transactional } \\
\text { and } \\
\text { interpersonal } \\
\text { dialogues } \\
\text { in daily life } \\
\text { context. }\end{array}$ & $\begin{array}{l}\text { 1.2 Respondi } \\
\text { ng } \\
\text { fluently } \\
\text { and } \\
\text { accuratel } \\
\text { y to the } \\
\text { meaning } \\
\text { of } \\
\text { transactio } \\
\text { nal (to } \\
\text { get things } \\
\text { done) and } \\
\text { interperso } \\
\text { nal (to } \\
\text { socialize) } \\
\text { dialogues } \\
\text {, formal } \\
\text { and } \\
\text { informal, } \\
\text { using } \\
\text { simple } \\
\text { oral } \\
\text { language, } \\
\text { which } \\
\text { involves } \\
\text { the } \\
\text { expressio } \\
\text { ns of } \\
\text { introducti } \\
\text { on,greetin } \\
\text { g/parting, } \\
\text { and } \\
\text { acceptanc } \\
\text { e of an } \\
\text { offer/invit } \\
\text { ation. } \\
\\
\text { 1.2 } \\
\text { Responding } \\
\text { fluently } \\
\text { and } \\
\text { accurately } \\
\text { to } \\
\text { the } \\
\text { meaning } \\
\text { of } \\
\text { transactiona }\end{array}$ & $\begin{array}{l}\text { Introducti } \\
\text { on, } \\
\text { Greeting/ } \\
\text { Parting } \\
\text { A: Pleased } \\
\text { to } \\
\text { meet } \\
\text { you. } \\
\text { B: Pleased } \\
\text { to } \\
\text { Meet } \\
\text { you } \\
\text { too. } \\
\text { Accepting } \\
\text { an offer/ } \\
\text { invitation } \\
\text { A: Come } \\
\text { to } \\
\text { my } \\
\text { party. } \\
\text { B: Thanks } \\
\text { for the } \\
\text { invitation } \\
\text { Accepting } \\
\text { a promise } \\
\text { A: I'll get } \\
\text { you } \\
\text { the } \\
\text { book. } \\
\text { B: It's } \\
\text { very } \\
\text { Kind } \\
\text { of you. } \\
\text { it some } \\
\text { other } \\
\text { Declining } \\
\text { a promise } \\
\text { A: I'm } \\
\text { sorry } \\
\text { I can't } \\
\text { make } \\
\text { it. } \\
\text { B: That's } \\
\text { OKe' } \\
\text { do } \\
\text { intl } \\
\text { int }\end{array}$ & $\begin{array}{l}\text { Listening } \\
\text { to } \\
\text { interperso } \\
\text { nal/transa } \\
\text { ctional } \\
\text { dialogues } \\
\text { through } \\
\text { tape } \\
\text { recorder } \\
\\
\text { Discussin } \\
\text { g any } \\
\text { expressio } \\
\text { ns used in } \\
\text { the } \\
\text { dialogues } \\
\text { (work in } \\
\text { pairs) } \\
\\
\text { Discussin } \\
\text { g any } \\
\text { response } \\
\text { given to } \\
\text { the } \\
\text { expressio } \\
\text { ns heard } \\
\text { (work in } \\
\text { groups) } \\
\text { Role- } \\
\text { playing } \\
\text { (work in } \\
\text { pairs) } \\
\\
\text { Doing } \\
\text { 'tourist } \\
\text { hunting'. } \\
\text { The } \\
\text { dialogue } \\
\text { in this } \\
\text { activity } \\
\text { will be } \\
\text { recorded }\end{array}$ & $\begin{array}{l}\text { Identifyin } \\
\text { g the } \\
\text { meaning } \\
\text { of the } \\
\text { expressio } \\
\text { ns of } \\
\text { introduct- } \\
\text { ion } \\
\\
\text { Respondi } \\
\text { ng to the } \\
\text { expressio } \\
\text { ns of } \\
\text { introduct- } \\
\text { ion } \\
\\
\text { Identifyin } \\
\text { g the } \\
\text { meaning } \\
\text { of the } \\
\text { expressio } \\
\text { ns of } \\
\text { accepting } \\
\text { an } \\
\text { offer/invit } \\
\text { ation } \\
\\
\text { Respondi } \\
\text { ng to the } \\
\text { expressio } \\
\text { ns of } \\
\text { accepting } \\
\text { an } \\
\text { offer/invit } \\
\text { ation } \\
\\
\text { Identifyin } \\
\text { g the } \\
\text { meaning } \\
\text { of the } \\
\text { expressio } \\
\text { ns of } \\
\text { accepting } \\
\text { a promise } \\
\text { ng to the } \\
\text { expressio } \\
\text { ns of } \\
\text { accepting } \\
\text { a promise }\end{array}$ & $\begin{array}{c}\text { Quizze } \\
\text { s } \\
\text { Writte } \\
\text { n } \\
\text { Tests }\end{array}$ & $\begin{array}{l}2 \mathrm{x} \\
45\end{array}$ & $\begin{array}{l}\text { Students' } \\
\text { workbook }\end{array}$ \\
\hline
\end{tabular}


2.

\begin{tabular}{|c|c|c|c|c|c|}
\hline $\begin{array}{l}\text { Understand } \\
\text {-ing the } \\
\text { meaning of } \\
\text { short } \\
\text { functional } \\
\text { texts and } \\
\text { simple } \\
\text { monologue } \\
\text { s in the } \\
\text { form of } \\
\text { recount, } \\
\text { narrative, } \\
\text { and } \\
\text { procedure } \\
\text { in daily life } \\
\text { context. }\end{array}$ & 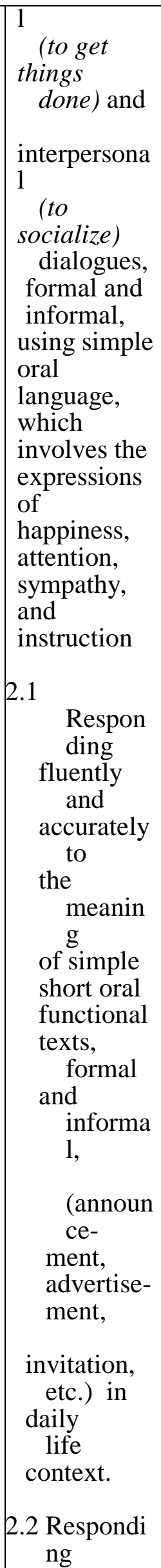 & time. & $\begin{array}{l}\text { Identifyin } \\
\text { g the } \\
\text { meaning } \\
\text { of the } \\
\text { expressio } \\
\text { ns of } \\
\text { declining } \\
\text { a promise } \\
\text { Respondi } \\
\text { ng to the } \\
\text { expressio } \\
\text { ns of } \\
\text { declining } \\
\text { a promise } \\
\\
\text { sing the } \\
\text { expressio } \\
\text { ns of } \\
\text { introducti } \\
\text { on } \\
\text { sing the } \\
\text { expressio } \\
\text { ns of } \\
\text { accepting } \\
\text { erforming } \\
\text { interperso } \\
\text { expressio } \\
\text { ns of } \\
\text { making a } \\
\text { promise } \\
\text { dialogues } \\
\text { sing the } \\
\text { expressio } \\
\text { ns of } \\
\text { accepting the } \\
\text { an } \\
\text { ns of an } \\
\text { ation } \\
\text { ation } \\
\end{array}$ & $\begin{array}{c}\mathrm{m} . \\
\text { Tests }\end{array}$ & $\begin{array}{l}2 \mathrm{x} \\
45\end{array}$ \\
\hline
\end{tabular}




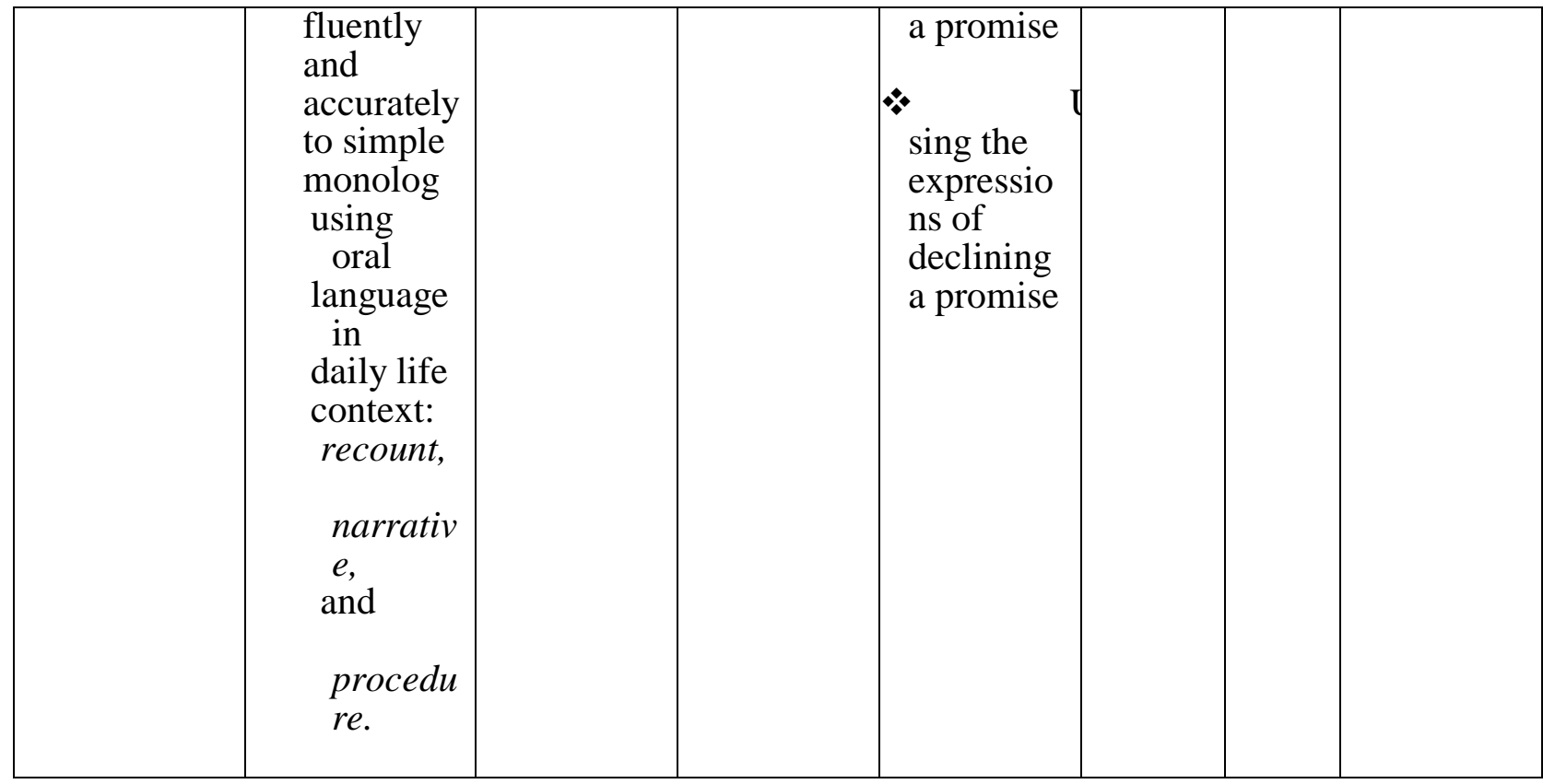

\section{Analysis}

In this respect, the researcher will analyse parts of the school-based curriculum development constructed by the English teachers in the regency with the exception of 'assessment' and 'resources'; details of both are not presented in the document. Aside from that, analysing parts of that document to the exclusion of the element 'resources' has encouraged researcher's recommendation for further research on it, particularly on student textbooks, workbooks, and other resources.

The document 'school-based curriculum development' which is used by the schools throughout the regency applies the so-called genre approach in its learning activities. Historically speaking, genre approach seems to be closer to social justice issues, particularly in 'inclusiveness' and 'equitable opportunity'. Feez (1998, p.24) contends that genre approach was first developed in Australia through the work of educational linguists and educators who have been working with disadvantaged groups of students. She also adds that this approach is based on three assumptions about language learning; language learning is social activity and the outcome of collaboration between the teacher and the student and between the student and other students in the group; learning occurs more effectively if teachers are explicit about what is expected of students; the process of learning will address both a level of independent performance and a level of 'potential performance' which is made possible through social interaction and joint construction with 'more capable others' such as parents or teachers (Gray 1987, p. 30 as cited in Feez). The following table shows how often the indicators for socially just curriculum are represented in the English school-based curriculum development.

Table 2: Socially Just Curriculum Indicators in the English School-based Curriculum Development

\begin{tabular}{|l|c|c|}
\hline \multicolumn{1}{|c|}{ Indicators } & $\begin{array}{c}\text { Yes/ } \\
\text { No }\end{array}$ & $\begin{array}{c}\text { No. of } \\
\text { Statement } \\
\text { S }\end{array}$ \\
\hline $\begin{array}{l}\text { VISION OF SOCIETY } \\
\text { Unity in diversity }\end{array}$ & & \\
Good care of motherland & Yes & 1 \\
Participation in society/democracy & Yes & 1 \\
Empowerment to act for socially just change & Yes & 2 \\
& & \\
\hline
\end{tabular}




\begin{tabular}{|l|c|c|}
\hline INCLUSIVENESS AND FAIRNESS & & \\
Inclusive language & No & 1 \\
Yes & 1 \\
Fair competition & Yes & 3 \\
Yquality of opportunity & 3 \\
Provision of access to important knowledge and skills to all & No & - \\
students & & \\
\hline $\begin{array}{l}\text { SOCIAL RESPONSIBILITY } \\
\text { Tolerance/Respect for people of different religions }\end{array}$ & \\
Valuing of all people/Respect for other people's rights & No & \\
- Looperation with other nations & Yes & 11 \\
Justice towards fellow people & Yes & 2 \\
Help for one another & Yes & 2 \\
\hline
\end{tabular}

Most of the learning materials of the document allude to the indicators 'valuing of all people' or 'respect for other people', demonstrated in the following examples:

A: Come to my party.

B: Thanks for the invitation.

A: Thank you for the invitation.

B: I look forward to seeing you.

A: I'm sorry I can't make it.

$B$ : That's OK. We'll do it some other time.

A: I'm so happy to get a scholarship.

B: I'm happy for you.

A: Pleased to meet you.

B: Pleased to meet you too.

From the above examples, thanking somebody for an invitation (example 1 and 2), apologizing for any inconvenience (example 3), and showing happiness for other people's achievement (example 4) can be the reflections of 'valuing of all people/respect for other people's rights', which could enhance students' social competence. Besides, the English expression 'pleased to meet you' (example 5) is considered polite way of greeting someone on meeting for the first time. In Indonesian culture, 'politeness' is the major key of maintaining social relations.

\section{A: You look fantastic.}

B: Thank you.

The above dialogue deals with the context in which A praises B for something, and B thanks A for the praise. The dialogue could provide students with learning not merely the terminology but a lesson how to 'respect each other' as well. As for the word 'pleased', 'praise' is also positive and is usually used to show approval for someone else' achievements or qualities.

The socially just curriculum indicators of both 'valuing of all people/respect for other people's rights' and 'help for one another' are covered in the examples below:

A: I'll get you the book.

$B$ : It's very kind of you.

A: Congratulations! You did it again. 


\section{VOL. 02 NO. 01, JUNE 2020}

\section{B: Thank you. I don't know what to do without you.}

The first conversation specifies that A promises to get the book for B, and B thanks A for his/her help, while the second demonstrates that A congratulates B for something good he/she has done, and B expresses his/her gratitude for A's help. These interactive and interpersonal dialogues can be good models for students to 'act socially at schools', and, later, in the society.

\section{A: Please accept my condolences. \\ B: Thank you.}

That is one example of expressing sympathy displayed in the document. Introducing this expression to students in the classroom context can practice their social sensitivity and awareness of the social reality that a particular bad thing could happen to anybody. Accordingly, having sympathy could meet other indicators such as 'love of human being' and 'help for one another'.

Moreover, in the learning stage, it is recommended that there should be an excursion study to the nearest tourist resort in the regency. This learning activity is termed as 'tourist hunting', in which the conversation with the English speaking tourists will be recorded for evaluation. From researcher's perspective, this activity is beyond English speaking practices, but rather it could urge students on a cultural study and maintain students' 'love of their own motherland' and 'cooperation with other nations' through the knowledge of local potency and understanding of foreign cultures. That kind of activity matches the rationale for the curriculum framework, which underpins students' understanding of the relationship between language and culture and preparing them for successful living in the global society. In addition to it, in the specimen of the text recount, it is written:

\section{Jim Carrey had a trip to Bunaken. Who went to Bunaken? \\ He went to Bunaken Island yesterday. Yesterday, he went to Bunaken. \\ To Bunaken, he went yesterday.}

According to the document, the focus of those specimens is on building students' knowledge of one particular linguistic feature, past tense. Nevertheless, mentioning the tourist resort of another region 'Bunaken', to where many English speaking tourists come, may be a sure way to make students recognize potency of their neighbouring areas, and thus elevate 'good care of motherland' for 'unity in diversity' and 'cooperation with other nations'.

Still in the learning stage, there is a phase of activity on which the students do 'peer correcting' as well as 'work in group discussions' for a particular draft accomplishment. These techniques can be referred to the socio-cultural theoretical perspective of Vygotsky (1978), specifying that human cognitive development occurs in social interaction between individuals in society (Feez 1998, p. 26). According to this theory, it is interactions between learners that will drive learning. The interactions may take the form of confirmation checks and clarification requests. At this stage, the peer correcting technique and work in group discussions could provide students with opportunities to give and receive feedback. From the perspective of the socially just curriculum indicators, peer correcting and work in groups constitute a social classroom activity which could stand at the point of 'participation in society', 'equitable opportunity', 'conformity with equal rights', 'respect for other people', and 'justice towards fellow people'.

Moreover,

\section{A: Thank you very much. \\ B: Don't mention it.}

Although the dialogue is simple, it is interactive and incorporates social actions where both A and B thank each other. From the perspective of this research, such a dialogue conforms to the socially just indicators 'valuing of all people/respect for other people's rights', 'conformity with equal degrees and rights', 'fairness', and 'equality of opportunity'.

However, in the learning material 'giving instructions', the dialogue below is contained:

A: Open the window! 


\section{VOL. 02 NO. 01, JUNE 2020}

\section{$B: O K$.}

Regarding the expression used in the dialogue, the context should be in informal situation, between close friends, and the like. Uttering such language to the elderly, parents, or teachers, based on the Indonesian culture, will be considered rude and disrespectful, and hence, in some cases, this part of the document is opposed to 'valuing of all people'. Accordingly, for being even-handed, it is suggested that the specimen of the learning material should also include the other formal type of expressions.

Besides, the document also incorporates the following model of conversation:

\section{A: You look slimmer. \\ B: You're kidding me.}

This utterance is used in an interpersonal communication on which A praises B for her/his physical condition. Whether or not B is pleased and excited about the praise certainly depends on the situational context that follows the communication. Nonetheless, from this perspective of research, the expression 'you look slimmer' will be regarded gendered bias and less inclusive if it is applied to classes containing students with various sexes and physical conditions. The word 'slim' means 'of attractively thin and well-shaped body' and, based on the samples of usage, is mostly used for describing women/girls (Collins Cobuild Dictionary, 2006). In addition, obese students may hesitate to take part in the conversation. Therefore, for inclusiveness and fairness, it is recommended that more inclusive words or phrases should be used in that kind of learning activity, or a description of someone's physical condition rather than achievement is to be avoided.

Hence, the English School-based Curriculum Development (SBCD) puts emphasis on students' 'social responsibility' particularly in terms of 'valuing of all people/respect for other people's rights'. In addition, the whole components in 'vision of society' are covered, but one point of each of the indicators 'inclusiveness and fairness' and 'social responsibility' is excluded; those are 'provision of access to important knowledge and skills to all students' and 'tolerance/respect for people of different religions'. The researcher has also discovered one statement which is against the point 'inclusive language' in 'inclusiveness and fairness'. With two points which are not represented and one point that is against the indicators, it could be stated that the English school-based curriculum development is less socially just in comparison to the English curriculum framework.

\section{CONCLUSION}

The State's Five Ideological Principles, Pancasila, is the basic foundation of social justice conception in Indonesia. The notion of social justice in Pancasila is in line with the liberal view, which sees 'social justice' as 'fairness', 'inclusiveness', 'equitable opportunity', and/or 'full participation in society'. According to the liberal vision, individual rights should be developed to attain social changes in society. At the school level, the liberals take the concept of 'inclusive curriculum' or 'inclusive practices' in the teaching-learning process. In this respect, education in general and educational curriculum in particular should be informed by a conception of social justice. Educational process is considered successful when it determines access to such goods as self-respect, respect for others, meaningfulness in one's work, etc. Accordingly, liberal social justice, when applied to education, will expect that all students deserve good education, due to its possible contribution to general equality of opportunity. In some cases, liberal education, too, provide all students with access to cultural elements, in order that students will respect for their own and other cultures.

Integrating social justice into educational curriculum, however, is not an easy task, for both 'social justice' and 'curriculum' themselves are contested terms. Prior to setting up the socially just curriculum indicators, one should have a sufficient understanding of social justice, curriculum, and socially just curriculum respectively.

Based on Pancasila as well as prominent scholars' viewpoints on the philosophical principles of social justice and curriculum, a set of indicators were developed to analyse the English curriculum framework and school-based curriculum development. The following parts reported on the analysis of each set of the documents. 


\section{VOL. 02 NO. 01, JUNE 2020}

With merely one component of the indicators excluded and no words and phrases opposing the indicators, the investigation results indicate that in most cases the centrally-based English curriculum framework for secondary schools reflects a socially just curriculum. It is more socially just compared to its extension, the school-based curriculum development; the latter does not contain two elements of the indicators, and one statement in it has been found against one point in the indicators.

Nevertheless, to pass judgment on whether, overall, the English curriculum is socially just is not a simple matter. In order to understand the application of social justice in the English curriculum, further research needs to be conducted. It would be necessary to talk with teachers and students, observe lessons, analyse more of the resources used by teachers, their methods of assessment, etc. Besides, the ministry of national education should offer more intensive trainings in curriculum development which place greater emphasis on the social justice aspects of the curriculum.

\section{REFERENCES}

Azra, A 2006, 'Indonesian Islam, Mainstream Muslims and Politics', paper presented at Taiwanese and Indonesian Islamic Leaders Exchange Project, The Asia Foundation in Taiwan, Taipei October 26-31 2006.

'Badan Standar Nasional Pendidikan Indonesia (Indonesian National Education Standard Board)' 2006, retrieved 22 May 2008 from

<www.bsnp-indonesia.org/>.

Baraldi, C 2008, 'Promoting Self-expression in Classroom Interactions', Childhood, Vol. 15(2), pp. 239-257.

Barlow, K 1989, ‘A Socially Just Curriculum', Education Links 36, Winter 1989, pp. 16-17.

Boucher, D \& Kelly, P 1998, Social Justice: From Hume to Walzer, Routledge, London.

Brady, L 1992, Curriculum Development (4th Edition), Prentice Hall, Australia.

Brady, L \& Kennedy, K 2003, Curriculum Construction, Pearson Education, Australia.

Bryman, A 2004, Social Research Methods, Oxford University Press, New York.

Connell, RW 1993, Schools and Social Justice, Pluto Press Australia, NSW.

Coonell, RW et al. 1994, 'The Issue of Poverty and Educational Measurement' in (Eds) E. Hatton, Understanding Teaching: Curriculum and the Social Context of Schooling, Harcourt Bruce, Sydney.

Eggleston, J 1977, the Sociology of the School Curriculum, Routledge \& Kegan Paul, London.

Feez, S 1998, Text-based Syllabus Design, Macquarie University, Sydney.

Gallego, MA 2001, 'Is Experience the Best Teacher?: The potential of Coupling Classroom and Community-Based Field Experiences', Journal of Teacher Education, Vol. 52, No. 4, September/October 2001, pp. 312-325.

Gay, G \& Kirkland, K 2003, 'Developing Cultural Critical Consciousness and Self-Reflection in Preservice Teacher Education', Theory Into Practice, Vol. 42, No. 3, Summer 2003, pp. 181-187.

Grundy, S 1994, 'The curriculum and teaching' in (Eds) E. Hatton, Understanding Teaching: Curriculum and the social context of schooling, Harcourt Brace \& Company, Australia.

Harrison, WD 2006, 'Human Ecology and Social Justice', Social Justice In Context, Carolyn Freeze Baynes Institute for Social Justice, East Carolina University.

Hitchcock, G \& Hughes, D 1989, Research and the Teacher: A Qualitative Introduction to School-based Research, Routledge, London

Hosen, N 2005, 'Religion and the Indonesian Constitution: A Recent Debate', Journal of Southeast Asian Studies, 36 (3), October 2005, pp. 419-440, the National University of Singapore.

'Kurikulum Bahasa Inggris 2006 (English Curriculum 2006)', retrieved 25 October 2007 from <www.puskur.net>. 
Marsh, CJ 1992, Key Concepts for Understanding Curriculum, the Falmer Press, London.

McDaniel, JE, Necochea, J, Rios, FA, Stowell, LP, \& Kritzer, C 2001, 'The Arc of Equity in Reinvented Middle Schools' in (Eds) T. Dickinson, Reinventing the Middle School, Routledge, New York.

Minogue, K 1998, 'Social justice in theory and practice' in (Eds) D. Boucher \& P. Kelly, Social Justice From Hume to Walzer, Routledge, New York.

Noddings, N 2003, 'Teaching Themes of Care' in (Eds) A.C. Ornstein et al, Contemporary Issues in Curriculum, Pearson Education, USA.

O’Bannon, B 2002, 'Planning for Instruction: Unit Plan', retrieved 8 July 2008 from

$\langle$ http://edtech.tennessee.edu/ bobannon/unit_plans.html>.

'Pancasila (Five Principles)', retrieved 8 April 2008 from $<$ http://en.wikisource.org/wiki/Pancasila>.

'Peningkatan Akses Masyarakat Terhadap Pendidikan Yang Lebih Berkualitas (Improving People's Access to More Qualified Education)' 2004, retrieved 3 October 2007 from

<http://agribisnis.deptan.go.id/web/dipertantb/produkhukum/bab_26_narasi.pdf.>.

Penny, D \& Walker, M 2007, 'Senior Secondary Schooling in Western Australia: Transforming curriculum, lives and society?', Curriculum Perspectives, Vol. 27, No. 3, September 2007, pp. 22-35.

'Peraturan Menteri Pendidikan Nasional Republik Indonesia Nomor 24 Tahun 2006(Ministry of National Education Regulations of Republic of Indonesia Number 24 Year 2006)' 2006, retrieved 8 April 2008 from

<www.puskur.net>.

Posner, GJ 1992, Analyzing the Curriculum, McGraw - Hill, New York.

Pozzuto, R 2006, 'Social Justice At The Level Of Everyday Life: Do We Need A Theory?', Social Justice In Context, Carolyn Freeze Baynes Institute for Social Justice, East Carolina University.

Preston, N 1996, Understand Ethics, Federation Press, NSW.

Print M 1987, Curriculum Development and Design, Allen \& Unwin, Australia.

'Qualitative Research Methods: Documentary Research', retrieved 28 September 2007 from <http://uk.geocities.com/balihar_sanghera/qrmdocumentaryresearch.html>.

Smith, DL \& Lovat, TJ 1993, Curriculum: Action on Reflection, Social Science Press, Australia.

Starr, K 1991, 'What is Social Justice?', Curriculum Perspectives - Newsletter edition September 1991.

Sturman, A 1997, Social Justice in Education, ACER Press, Australia.

Taki, S 2008, 'International and local curricula: The question of ideology', Language Teaching Research, Vol. 12(1), pp. 127-142. 